\title{
Biochemical Approach to Assess Groundwater Pollution by Petroleum Hydrocarbons (Case Skikda Algeria)
}

\author{
Sofiane Labar ${ }^{1}$, Azzedine Hani ${ }^{2}$, Larbi Djabri ${ }^{2}$ \\ ${ }^{1}$ Institute of Sciences of Nature and Life, University of El-Tarf, El-Tarf, Algeria \\ ${ }^{2}$ Department of Geology, University of Annaba, Annaba, Algeria \\ Email: labar_sf@yahoo.fr
}

Received February 3, 2012; revised March 10, 2012; accepted April 16, 2012

\begin{abstract}
Due to the accelerated population growth and development in all sectors especially industry, more water has been pumped and more effluents have been rejected to the natural system. In the coastal Skikda Valley; Petrochemical industry is practiced along the year and almost groundwater are threatened. This work is referred to the characterization of the environmental hydrobiochemistry in the coastal petrochemical industrial area. The study has investigated the groundwater pollution by hydrocarbons using biochemical approach and assessing the nature and extent of contamination of groundwater in relation to petroleum industrial activities surrounding tank, channel and pipe. At site of this industrial zone, groundwater circulates on slight deep in the mio-pliocene alluviums (sand and gravel) which is characterized by an important permeability. Groundwater quality analysis proved that groundwater quality is largely polluted with respect to $\mathrm{BOD}_{5}, \mathrm{COD}, \mathrm{TPH}$ and TSS. So, a narrow relationship between BOD and TPH and important qualitative degradation of the groundwater is shown, especially in the parts situated in the down gradient area and in direct proximity of tank, channel and pipe. The extent of groundwater contamination is influencing by the depth of the water table, permeability of the soil and therefore infiltration rate. In order to prevent further pollution of groundwater, oil must be stored and transported via impervious tank, pipe and channel. So, effluents must be treated prior to discharge.
\end{abstract}

Keywords: Groundwater; TPH; Biochemical Parameters; BOD; ; Algeria

\section{Introduction}

Groundwater is one of the most precious natural resources in the north east of Algeria as it is the principal source of drinking water for the majority of the population. The groundwater aquifer of Skikda region is extremely susceptible to surface-derived contamination because of the high permeability of sands and gravels that compose the soil profile of East Skikda region [1-3]. Several studies in Skikda region reported various degradations levels of groundwater as one of the major concerns among the public and governmental decision makers [1-4], but these studies did not include a biochemical approach to evaluate groundwater contamination.

Skikda city is located in the northeast of Algeria and occupies an area of around $4138 \mathrm{~km}^{2}$. The population has increased greatly to some 800,000 inhabitants. The demographical development and the intensification of the economic industrial activities in Skikda have been accompanied by an increase in demand for water. There are about 135 groundwater wells in the Skikda region and the amount of groundwater abstracted from these wells has been estimated to be about $52 \mathrm{hm}^{3}$ per year with 12 $\mathrm{hm}^{3}$ per year being abstracted from the industrial zone.
Such large industrial demands on groundwater have caused water quality and the contamination of groundwater in this coastal zone to become an extremely important issue for industrial groundwater supply. Groundwater contamination should be largely dependent on petroleum industrial waste and effluents of channel, tank and or pipe. This study was designed to elucidate the hydrobiochemical characteristics and the contamination of groundwater by hydrocarbons by using a biochemical approach according to industrialization and land use patterns.

The remainder of this paper is organized as follows. In Section 2 we present an overview of the general characteristics of the study site. Section 3 presents materiel and methods and how biohemical approach is used. Related work and results is discussed in Section 4, and finally, the paper is concluded with an outlook on future work in Section 5 .

\section{Site Characteristics}

The study of the vulnerability of groundwater to pollution using natural characteristics by means of the DRASTIC method [5] has shown that our area is located 
in the zone of moderate to high vulnerability. The climate is of humid type with an annual rainfall of $733 \mathrm{~mm}$, a mean annual temperature of $18^{\circ} \mathrm{C}$ and the prevailing winds direction is from the industrial towards the residential part of the city. The total infiltration in the alluvial water-table of Skikda is around 33\% of the total rainfall, approximately $240 \mathrm{~mm}$ per year infiltrates through soil to the water table. The studied zone, which is a part of northeast Algerian coast, is formed by a Paleozoic substratum overlaid by Mesozoic and mio-plioquaternary continental and lagoonal sediments. The aquifer system is characterized by a superficial table (alluviums " $15 \mathrm{~m}$ of thickness") and a captive table which is fundamentally constituted by gravels (gravel table, "10 - 40 m of thickness").

\section{Material and Methods}

Many monthly surveys of the piezometric level and geochemical analysis have been monitored on dry and wet period. The analyses are carried out on network of 19 piezometers (one to two wells per $\mathrm{km}^{2}$ ) surrounding tank, channel and pipe. Three samples of industrial effluents were sampled from a drainage channel within the Industrial zone. The temperature (T), $\mathrm{pH}$ and electrical conductivity (EC) were measured in situ using a handheld meter (WTW Multiline P3 PH/LF-SET, CellOx 325). The concentration of chloride $\left(\mathrm{Cl}^{-}\right)$, carbonates $\left(\mathrm{HCO}_{3}^{-}\right)$ and sulfates $\left(\mathrm{SO}_{4}^{2-}\right)$ were measured using the volumetric method [6]. The total suspended solids (TSS) was determined by filtration through a standard GF/F glass fiber filter (NF EN 872). The chemical oxygen demand (COD) was measured by COD meter (Tract $42 \mathrm{~mm}$ RIN 29/32 and refrigerant RIN 29/32). The biochemical oxygen demand $\left(\mathrm{BOD}_{5}\right)$ was measured by intelligent system BOD meter (WTW DIN 38 409). The phosphate $\left(\mathrm{PO}_{4}^{3-}\right)$, Nitrate $\left(\mathrm{NO}_{3}^{-}\right)$, Nitrite $\left(\mathrm{NO}_{2}^{-}\right)$, and ammonium $\left(\mathrm{NH}_{4}^{+}\right)$ were analyzed by colorimetery method using spectrophotometer (Spectronic $20 \mathrm{D}$ ). The total petroleum hydrocarbons (TPH) was measured and calculated by infrared (IR) determination. The piezometric level map was grided by the golden Software Surfer (Version 9.8), using the Kriging method.

\section{Results and Discussion}

\subsection{Piezometric Level Study}

The groundwater table (Figure 1) is characterized by shallow depths (generally inferior to $7 \mathrm{~m}$ with a minimum of $0.8 \mathrm{~m}$ ). These depths were observed down the gradient of the drainage channel and in the coastal zone. The over flow direction of the aquifer was SW-NE. The presence of shallow depth piezometric level within the coastal area indicates a seawater intrusion in the Industrial zone. However, this potential source of pollution has

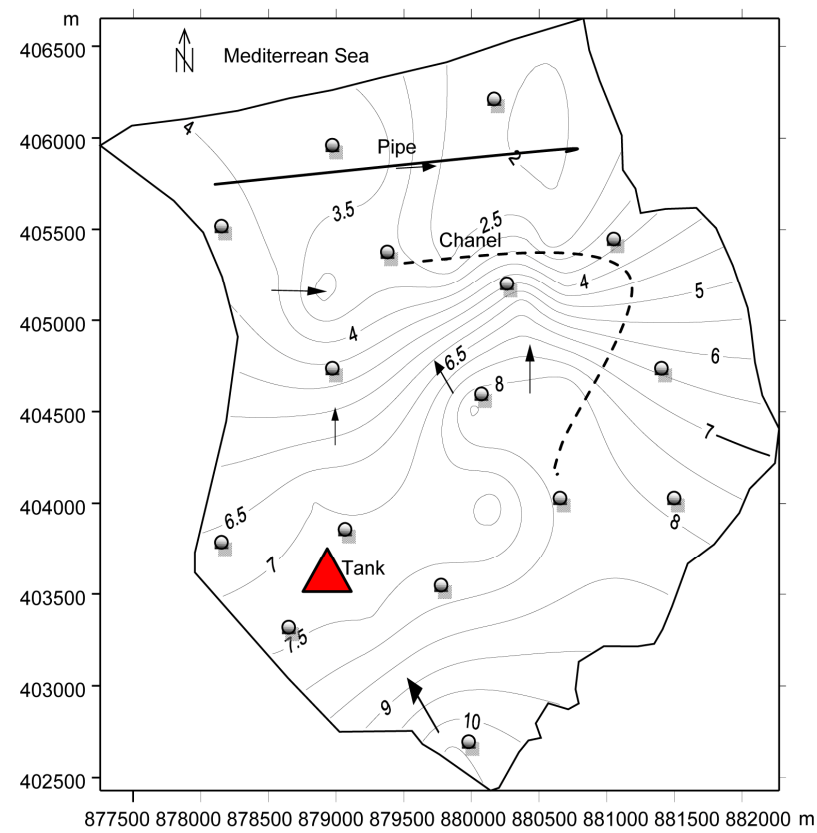

Figure 1. Piezometric level map (m).

been stimulated by effluent of seawater pumped to chill hot industrial equipments [3].

So, the conductivity in the source of the effluent of seawater pumped is about $22 \mathrm{~ms} / \mathrm{cm}$ and $8 \mathrm{~ms} / \mathrm{cm}$ in the drainage channel (average $4 \mathrm{~ms} / \mathrm{cm}$ in all effluent points, Table 1) but in the groundwater at the same area is about $2 \mathrm{~ms} / \mathrm{cm}$.

\subsection{Chemical Composition of Effluents}

The effluents originating from industrial factories are highly concentrated (Table 1) with copper sulfate (938 $\mathrm{mg} / \mathrm{l})$, nitrates $(24 \mathrm{mg} / \mathrm{l})$ and phosphates $(9 \mathrm{mg} / \mathrm{l})$. These high values of nitrates and phosphates explain the eutrophication of ground water in this petroleum industrial area.

\subsection{Characterization of Pollution}

The pollution of groundwater by organics was characterized by high values of total hydrocarbons (Figures 2, 3 and 4) above limit suggested by the World health Organization $(0.001 \mathrm{mg} / \mathrm{l})$ [7] on all most throughout the year [3] near tank, channel and pipe (Figures 3 and 4).

The biochemical pollution identified by biochemical parameters [8] $\left(\mathrm{BOD}_{5}, \mathrm{COD}\right.$, TSS) has shown for a dry and a wet periods above target value by a high concentration of BOD and COD for all effluent and groundwater points (Figures 2, 3 and 4). Some rivers (Kebir-Est, Bounamoussa and Seybousse) of El-Tarf nearest region have shown the same case of pollution by organics [9] but without petroleum hydrocarbons because the specific agricultural activities in this site. 
Table 1. Basic statistics of chemical parameters of water effluent samples (2010-2011).

\begin{tabular}{ccccccccccc}
\hline & $\mathrm{PH}$ & $\mathrm{EC} \mu \mathrm{s} / \mathrm{cm}$ & $\mathrm{Cl}^{-} \mathrm{mg} / \mathrm{l}$ & $\begin{array}{c}\mathrm{SO}_{4}^{2-} \\
\mathrm{mg} / \mathrm{l}\end{array}$ & $\begin{array}{c}\mathrm{HCO}_{3}^{-} \\
\mathrm{mg} / \mathrm{l}\end{array}$ & $\begin{array}{c}\mathrm{NO}_{3}^{-} \\
\mathrm{mg} / \mathrm{l}\end{array}$ & $\begin{array}{c}\mathrm{NO}_{2}^{-} \\
\mathrm{mg} / \mathrm{l}\end{array}$ & $\begin{array}{c}\mathrm{NH}_{4}^{+} \\
\mathrm{mg} / \mathrm{l}\end{array}$ & $\begin{array}{c}\mathrm{PO}_{4}^{3-} \\
\mathrm{mg} / \mathrm{l}\end{array}$ \\
\hline \multirow{2}{*}{$\begin{array}{c}\text { Dry } \\
\text { period }\end{array}$} & Min & 6.83 & 962 & 102 & 96 & 281 & 28 & 0 & 1 & 0.5 \\
$(2010)$ & Average & 7.173 & 3915.333 & 739.303 & 888.637 & 605.324 & 33.304 & 0.109 & 15.701 & 7.819 \\
& St. Dev. & 0.426 & 5034.998 & 923.795 & 1351.897 & 552.843 & 5.130 & 0.135 & 24.671 & 11.8 \\
& Min & 7.45 & 883 & 68 & 74 & 272 & 19 & 0 & 0.8 & 2 \\
$\begin{array}{c}\text { Wet } \\
\text { period }\end{array}$ & Max & 8.35 & 8930 & 1642 & 2235 & 1156 & 30 & 0.24 & 40 & 20 \\
$(2011)$ & Average & 7.827 & 3593.667 & 598.701 & 802.269 & 570.005 & 25.436 & 0.1 & 14.125 & 7.322 \\
& St. Dev. & 0.27 & 2668.279 & 903.984 & 1240.898 & 507.451 & 5.632 & 0.124 & 22.646 & 10.630 \\
\hline
\end{tabular}

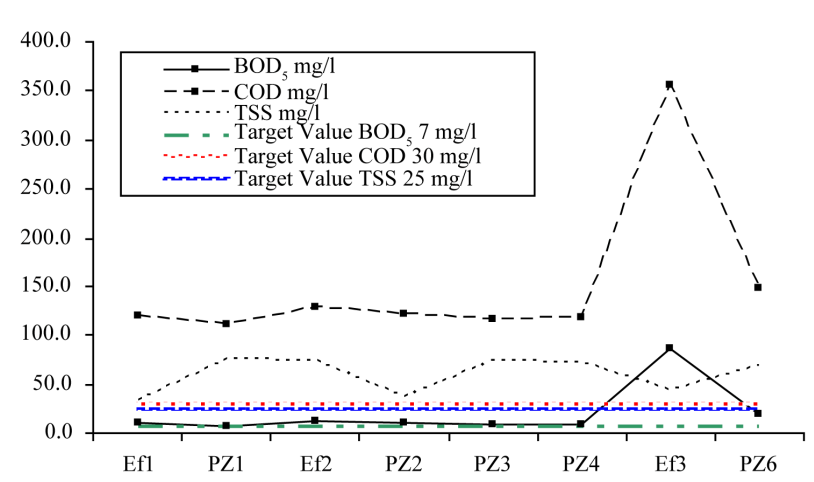

Figure 2. Spatial evolution of biochemical pollution $\left(\mathrm{BOD}_{5}\right.$, COD and TSS).

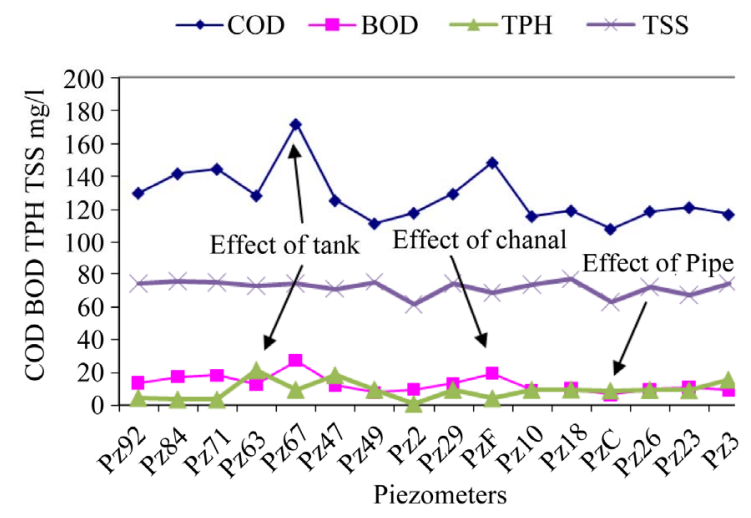

Figure 3. Spatial evolution of pollution and relationship between biochemical parameters and TPH on a dry period (Low level of groundwater).

Figure 3 shows that the quality of groundwater on a dry period is characterized by high effects of tank, channel and pipe.

Figure 4 shows that the quality of groundwater on a wet period is characterized by high effects of tank and pipe. So, a moderate effect by channel because of dilution by precipitation.

Figures $\mathbf{3}$ and $\mathbf{4}$ both show clearly a narrow relationship between BOD and TPH and important qualitative degradation of the groundwater is shown, especially in

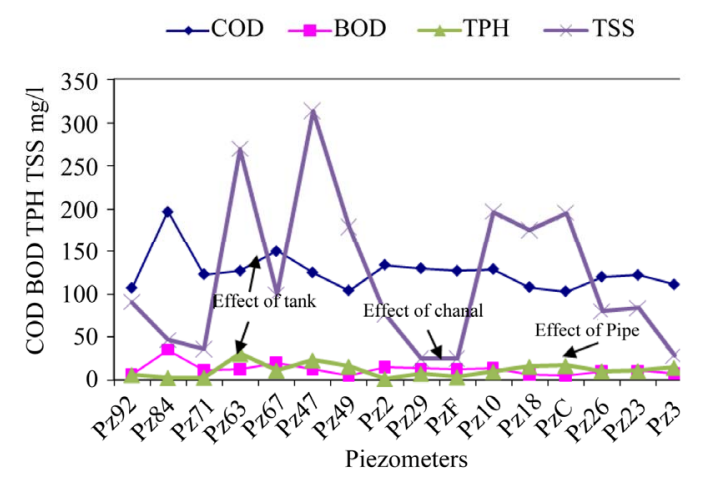

Figure 4. Spatial evolution of pollution and relationship between biochemical parameters and TPH on a wet period (High level of groundwater).

the parts situated in the down gradient area and in direct proximity of tank, channel and pipe.

\section{Conclusions}

Our hydrobiochemical study by using a biochemical approach to identify water pollution by hydrocarbons shows that groundwater in the vicinity of petroleum industrial effluents are characterized by high level of biochemical and organically pollution especially due to its locations near tank pipe and drainage channel.

The biochemical approach especially with biochemical oxygen demand $\left(\mathrm{BOD}_{5}\right)$ presents good results for assessing groundwater contamination by hydrocarbons (crude oil).

Certainly exposure to crude petroleum (crude oil), or its complex chemical constituents, can cause toxic effects in humans, livestock and other animal species [10].

To prevent further deterioration of groundwater quality a number of measures are recommended, namely:

- To establish an appropriate system for the collection, treatment and discharge of effluents;

- Introduce impermeable surfaces in the tank, the drainage channels and pipe e.g. using clay or high density polyethylene geomembrane or other suitable structure 
and equipment;

- To monitor groundwater quality carefully across a network of representative wells over an extended time period.

Although crude oils from various geological areas are known to cause various biochemical and cytological alterations in animal species [11].

Biochemical changes in cytochrome P-450 (CYP) isoforms and associated polysubstrate monooxygenase (PSMO) activities in animals exposed to various lipophilic substances are reported to be valuable biomarkers of early-stage systemic events [12].

It's important to study the systemic effects of low doses of an ACO on selected PSMO activities and the distribution of biomarker chemicals (hydrocarbons) to adipose tissues in animals like rats [13].

\section{Acknowledgements}

We are grateful to director of Skikda environmental direction and the staff of the health, security and environment (HSE) department of the company of management of the industrial zone of Skikda "EGZIK". The ground and field works have conducted in collaboration with them.

\section{REFERENCES}

[1] F. Djaiz, “Contribution à l'Etude Petro-Structurale du Secteur de Bouchtata-Tamalous-Bordure Orientale du Socle de la Petite Kabylie (Algérie Nord-Orientale)," Université Mentouri Constantine, Algérie, Sciences \& technologie D, No. 27, 2008, pp. 71-76.

[2] O. Kolli, "Pb-Zn-Cu Mineralization in the Filfila Massif, Northeastern Algeria," Proceedings of the Eighth Biennial SGA Meeting, Chapter 4-17, Beijing, 18-21 August 2005, Springer Berlin Heidelberg, pp. 417-420.

[3] S. Labar, A. Hani, C. Cunningham and A. Younsi, "Pollution Control of Groundwater Whiting an Industrial Zone (Skikda, Algeria)," Proceedings of the Fourth Conference Watershed Management to Meet Water Quality Standars and TMDLS (Total Maximum Daily Load), San Antonio, 10-14 March 2007, pp. 264-270.

[4] L. Mézédjri, A. TahharAli and A. B. Djebar, "Statistical Approach on the Impact of the Activity of Industrial Zone of Skikda on the Quality of the Waters of Saf-Saf Wadi
(Skikda Algerian East Coasts)," European Journal of Scientific Research, Vol. 20, No. 2, 2008, pp. 343-347.

[5] H. Chaffai, R. Laouar, L. Djabri and A. Hani, "Eude de la Vulnérabilité à la Pollution des eaux de la Nappe Alluviale de Skikda: Application de la Méthode Drastic,” Bulletin du Service Géologique National, Vol. 17, No. 1, 2006, pp. 63-74.

[6] AFNOR, “Eau, Méthodes d'Essai,” Association Française de Normalisation, Edition, Paris, 1989.

[7] WHO, “Guidelines for Drinking Water Quality," 3rd Edition, Vol. 1, Recommendations 1sAddendum, Geneva, 2006, 515 p.

[8] L. Chery and C. Mouvet, "Prin Cipaux Processus Physico-Chimiques et Biologiques Intervenant dans l'Infiltration des Produits Polluants et leur Transfert vers les Eaux Souterraines,” La Houille Blanche, No. 718, 2000, pp. 82-88.

[9] S. Labar, A. Hani and N. Zenati, “Approche de Caractérisation Bio-Physico-Chimique de la Pollution Industrielle (Cas des Unités de Transformation et de Conservation de la Tomate)," Proceedings of the ler Séminaire International sur l'Environnement et ses Problèmes Connexes (SIEPC’2005), Béjaia, Algeria, 5-7 June 2005, p. 212.

[10] H. N. MacFarland, C. E. Holdsworth, J. A. MacGregor, R. W. Call and M. L. Lane, "Applied Toxicology of PetroleumHydrocarbons,” In: Advances in Modern Environmental Toxicology, Vol. 6, Princeton Scientific Publishers Inc, Princeton, 1984, p. 287.

[11] A. A. Khan and M. M. Schuler, "Biochemical Toxicology of Oilfield Chemicals in Cattle,” In: G. E. Chalmers, Ed., A Literature Review and Discussion of the Toxicological Hazards of Oilfield Pollutants in Cattle, Alberta Research Council, Vegreville, 1997, pp. 149-161.

[12] T. D. Bucheli and K. Fent. "Induction of Cytochrome P450 as a Biomarker of Environmental Contamination in Aquatic Ecosystems," Critical Reviews in Environmental Science and Technology, Vol. 25, No. 3, 1995, pp. 201268. doi:10.1080/10643389509388479

[13] A. Khan, R. W. Coppock, M. M. Schuler and L. Geleta. "Biochemical Changes as Early Stage Systemic Biomarkers of Petroleum Hydrocarbon Exposure in Rats," Toxicology Letters, Vol. 134, No. 1-3, 2002, pp. 195-200. doi:10.1016/S0378-4274(02)00188-1 